\title{
Are Remittances to Sub-Saharan Africa Altruistic or for Self-Interest? Evidence from Kenya
}

\author{
John Kagochi ${ }^{1} \&$ Chien-Ping Chen ${ }^{1}$ \\ ${ }^{1}$ School of Business Administration, University of Houston-Victoria, USA \\ Correspondence: Chien-Ping Chen, School of Business Administration, University of Houston-Victoria, 14000 \\ University Blvd, Sugar Land, TX 77479, USA. Tel: 1-281-275-8811. E-mail: chenc@uhv.edu
}

Received: September 17, 2013

Accepted: October 18, $2013 \quad$ Online Published: November 26, 2013

doi:10.5539/ijef.v5n12p70

URL: http://dx.doi.org/10.5539/ijef.v5n12p70

\begin{abstract}
International remittances comprise significant financial inflow for many Sub-Saharan African (SSA) countries and provide considerable disposable income for the receiving households. There has, however, been no consensus on the motivation in the part of sending migrants in which explanations are divided between altruism and self-interest. The study employs Autoregressive Distributed Lag (ARDL) model with co-integration approach to investigate whether international remittances to Kenya can be explained by either altruistic or self-interest motive. We process the World Bank annual data from 1970 to 2010 and find that self-interest, not altruism, as the dominant motivation to determine remittances. The analysis also indicates that demand on housing and exchange rates are the two strong drivers of international remittances to Kenya in both short-run and long-run. The Kenyan government is supposed to facilitate savings from remittances through financial institutions to invest more in the small business sector for economic growth.
\end{abstract}

Keywords: remittances, altruism, self-interest, Sub-Saharan Africa, Kenya

\section{Introduction}

The importance of remittances in a developing country's economic development has been raising attention and discussion among academics, private sectors and policy makers. World Bank (2011) shows that worldwide remittances construct nearly two-thirds of Foreign Direct Investment (FDI) to developing countries and the inflow amount is more than two times of the total official development funds. There has been a long debate on the motives affecting a migrant's decision making to remit. Prominent among those motivations are altruism and self-interest. According to Becker (1974), altruism is giving without regard to reward or the benefits of recognition and need. It can be an important factor in decision making for remittance especially when immigrants have to financially support families back home. On the other hand, self-interest motivation for remittance is considered when a migrant is unwilling or not able to find good investment opportunities in the host country and, therefore, decides to invest back home. Migrants remit because they benefit from household gratitude after they return back home which can appear as a reflection of household inheritance. To the government in developing countries, it has been significantly important to verify which motivation is more dominant in remittance, altruism or self-interest, to facilitate the inflow money as the driving force for economic growth.

There have been numerous studies on motivation for international remittances in Eastern Europe and Latin America. However, the findings may not fit the other developing countries, especially for those in Africa with a relatively lower share but a faster growing remittance flow. Among them, Sub Saharan Africa (SSA), constructing the lowest amount of remittances in Africa, more than doubled the inflow from $\$ 9.6$ billion to $\$ 21.5$ billion in the period of 2005 to 2010 (World Bank, 2011). Although the increase was remarkable, remittances to the region still counted less than 6 percent of global developing countries during the same period. Different from the other developing countries, the majority of SSA has the highest share of poverty population and the lowest share of immigrants to developed countries. In 2010, only $24.8 \%$ of the immigrants from SSA went to high-income OECD countries while $2.5 \%$ migrated to high-income non-OECD countries. The rest $63.0 \%$ were the intra-regional migration, often not depicted in the statistics (World Bank, 2011). Although there is still lack of empirical research for remittance motivation to SSA, it is commonly expected that altruism and charity are embedded into the culture of people who originate from this region and one would expect altruism to be the 
dominant motivation for international remittances to this region.

Among SSA countries, Kenya raises our interest in exploring the motivation of remittances by the following rationales. First, Kenyan worldwide immigrants have grown fast and remittances have increased dramatically (e.g. $\$ 530$ million in 2003 to $\$ 1.8$ billion in 2010). Kenya is also ranked as the third largest remittance recipient in SSA (World Bank, 2011). Second, remittances count as the largest component in foreign income for Kenya and contribute 5.4\% in its GDP. In addition, as Bendixen (2010) indicates, like most African countries, Kenya government does not implement or propose any policy to channel the remitting inflows for its economic growth. Only a miserable $4 \%$ of receiving remittances are kept as savings for investment. Finally, to our knowledge, there is still lack of investigation on the motivation for remittances subject to Kenya.

This paper seeks to fill the literature gap of remittance motivation and provides recommendation for Kenyan government policy making. We process the World Bank annual data from 1970 to 2010 to estimate the long-run determinants for international remittances to Kenya by employing the Autoregressive Distributed Lag (ARDL) model with co-generation approach renovated by Pesaran, Shin, \& Smith (2001). We find that self-interest rather than altruism dominates as the motivation in international remittances to Kenya. Housing construction demand and exchange rate are the two strong drivers of international remittances to Kenya. Also, the economic status of immigrants' host country is strongly related to the amount of remittances. The rest of the paper is organized as follows. Section 2 discusses a brief literature review. The model specification and data are shown in Section 3. Section 4 presents econometric methodology and interprets the results. Concluding remarks and policy recommendations are in the last section.

\section{Literature Review}

Previous studies have provided quite mixed results for the impacts from remittances on a recipient country's economy, especially in developing countries. Opponents of remittances argue that remittances enlarge income inequality since rich families are more capable to send migrants oversea then they will remit more back home making their households even richer. Ratha (2004) indicated that large money inflows may weaken the receiving country's relative competitiveness in international trade due to an appreciation of real exchange rate. For small developing countries where remittance constructs a relatively higher share in their GDP, Catrinescua, Leon-Ledesmab, Pirachac, \& Quillind (2009) confirmed the negative impact of remittances which not only restricts exports but also limits employment and output. Examining Eastern European countries, Leon-Ledesma and Piracha (2004) found that remittances lower the shadow price of market wage in recipient countries. Individuals who receive remittances are expected to reserve a higher wage to enter labor market.

On the other hand, several studies support remittances as a positive impact on relatively poor economy. In addition to improve the living standard of poor recipients, Roberts and Banaian (2004) claimed that remittances also serve as a vehicle to expand financial market in which recipient households tend to investment in education and healthcare. Furthermore, Woodruff and Zenteno (2004) found that remittances promote entrepreneurial activities by relaxing the financial constraints for small business especially in developing countries. Both productivity and employment are improved through the positive impact of remittances on investment. Leon-Ledesma and Piracha (2004) and Thanh (2009) also recognized a strong potential for remittances to promote community development and enhance gross national product (GNP) in developing countries.

Either altruism or self-interest plays the most important role in remittance decision making for those who migrate due to poverty in their home country. Altruism has been defined as the willingness to give part of one's time or resources for a good cause and the willingness to give has to be in the giver's utility function; otherwise, it will be considered as obligatory (Becker, 1974). According to Tchouassi (2010), the altruistic model assumes that sending remittances yields a satisfaction to the migrant out of a concern for the social welfare of his family, community, or country. If altruism is the most important motivation, the remittance flows are expected to be stable at national level for the receiving countries. As a result, it is more likely that families receiving money from oversea will routinely depend on such flows in the future. The inflows to the families are also expected to increase when the receiving countries experience economic downturn (Bouhga-Hagbe, 2006).

In contrast, self-interest motivation to remittance is considered especially when a migrant is unwilling or not able to find investment opportunities in the host country and, therefore, chooses to invest back home. Lucas and Stark (1985) indicated that remittances are actually on the purpose of insurance for migrants' own self-interest. They expect the receiving families will reciprocate when they fall into economic hardship in the host country. Brown (1997) defined the self-interest motivation as the expected return from investment back home and the possible changes in family inheritance affect migrants' decision making in remittances. When immigrants remit to the household paying for them in the past, especially in education, remittances are also viewed as return of 
investment incurred to facilitate the transition abroad (Poirine, 1997).

Like most SSA counties, Kenya is too poor to provide sufficient social support for citizens who earn their living through subsistence agriculture. Tchouassi (2010) indicated that social security for the majority in those countries is provided by family members and clan, or the ethnic groups through giving and sharing. It is therefore expected that altruism and charity are embedded into the culture of people who originate from this region and one would expect altruism to be the largest motivation for international remittances to this region. However, none of the previous studies investigates empirically about the altruism motivation for Kenya.

\section{Model Specification and Data Description}

\subsection{Model Specification}

Following Lucas and Stark (1985) and Funkhouser (1995), we consider one migrant $(m)$ and one recipient household $(h)$ which may consist of one or more individuals. Similar to Funkhouser (1995), a separable total utility function for the migrant contains his or her own utility, $U_{m}$, and the value $V$ of the recipient household utility, $U_{h}$, such that

$$
U\left(U_{m}, U_{h}\right)=U_{m}\left(C_{m}\right)+V\left\{U_{h}\left(C_{h}\right), A\right\},
$$

where $C_{m}$ and $C_{h}$ denote the consumption of migrant and household respectively; $A$ is the importance of utility of the household left behind in the migrant's own utility, or the degree of the migrant's attachment to home country. The utility functions satisfy the concave properties as $U_{m}^{\prime}>0, U_{h}^{\prime}>0, U_{m}^{\prime \prime} \prec 0$, and $U_{h}^{\prime \prime} \prec 0$. The migrant maximizes the separable lifetime utility function by choosing $R_{t}$, the nominal remittance expressed in home country currency in period $t$ :

$$
\max _{R_{t}} U_{m}=\sum U_{m}\left\{C_{m t}\right\} /\left(1+\delta_{u}\right)^{t}+V\left\{U_{h}\left(Y_{h t}+e_{t} R_{t}+N_{h t} e_{t} \bar{R}\right), A\right\} /\left(1+\delta_{v}\right)^{t}
$$

subject to

$$
C_{m t}=Y_{m t}-R_{t}
$$

where $C_{m t}$ is consumption of the migrant at time $t ; Y_{m t}$ is the income earned by the migrant in the host country at time $t ; Y_{h t}$ is the income of the recipient household; $e_{t}$ is the real exchange rate between the host and home country; $\bar{R}$ is the average remittances received from other migrants who work in the same host country; $N_{h t}$ is the total number of migrants from the home country to the host country. Finally, $\left(1+\delta_{u}\right)^{-t}$ and $\left(1+\delta_{v}\right)^{-t}$ are the time discount rates applied to the migrant's own utility and the value of recipient household utility, respectively. It is also assumed that migrant does not participate in the host country stock or debt market. Therefore, $Y_{m t}$ is either consumed or remitted to the country of origin.

The first-order condition for a positive level of remittances in time $t$ is given by

$$
-\left[U_{m}^{\prime} /\left(1+\delta_{u}\right)^{t}\right] d R+\left[\partial V / \partial U_{h}\left(U_{h}^{\prime}\right)\right] /\left(1+\delta_{v}\right)^{t} d R=0 .
$$

Equation (4) shows that an incremental increase in utility from additional household income as a result of remittance offsets the decrease in the migrant's utility by his or her lower consumption in the host country due to the money transfer. As noted by Funkhouser (1995), a corner solution to the maximization problem leads to either a censored regression model or self-selection model. In both cases, the optimal solution can be derived as a reduced form equation for the determinants of remittances:

$$
R_{t}=f\left(Y_{m t}, Y_{h t}, e_{t}, N_{h t}, A\right) ;
$$

the expected signs for $Y_{m t}, e_{t}$ and $N_{h t}$ are positive while the sign of $Y_{h t}$ is expected to be negative.

There are several general implications from the model including that a migrant with higher income is supposed to remit more and a lower income household receives more. Remittances increase with both the degree of proximity between the migrant and the recipient household members, and the migrant's intentions to return. At macro level, more migrants will lead to a higher total remittance. Real exchange rate (e) appreciation in the home country is expected to reduce remittances from oversea and vice versa. We therefore expect a positive relationship between the real exchange rate and remittances which are expressed in the host country's currency. It is also expected that remittances will increase with the degree of migrant's attachment to his family in country of origin $(A)$ which is consistent with the literature on trans-nationalism. As noted by Guarnizo (2003), transnational migration refers to immigrants that settle down and become well integrated in the host country but still maintain social, cultural, economic and political ties with their home country.

Given the derived properties in the above, we construct the following log-linear model to estimate the international remittances to Kenya as 


$$
\operatorname{lnRem}_{t}=\alpha_{0}+\alpha_{1} \ln Y_{t}+\alpha_{2} U S_{t}+\alpha_{3} \ln H D_{t}+\alpha_{4} \ln E X_{t}+\alpha_{5} I N F L_{t}+\alpha_{6} D t_{t}+\varepsilon_{t}
$$

In (6), lnRem denotes the log of the share of international remittances to the recipient country's real GDP. $Y$ and US are the agricultural GDP per capita and the U.S. unemployment rate, respectively. According to more than 50\% of Kenya's remittances are originated from the U.S., the $U S$ is considered as an appropriate proxy for estimation (Bendixen, 2010). The business cycles of the two countries are assumed to be independent since they are lowly intertwined geographically and economically. $H D$ denotes the domestic cement consumption; $E X$ denotes the real exchange rate; INFL measures of price inflation in the recipient home country. In addition, due to Kenyan agricultural economy, we add $D t$ as the dummy variable for drought years that takes the value of 1 , when there is drought within the year.

\subsection{Data Sources and Description}

We investigate annual data for Kenya covering 1970-2010 from World Bank (2011). The dependent variable, remittance (Rem) is expressed in U.S. dollar and counts the transfers from migrants to recipient households including (1) cash or in kind, (2) employee compensation such as wages, salaries, and other remuneration, and (3) capital assets. There are two limitations about the World Bank remittance data. First, it counts the transfers made by immigrants who reside in the host countries longer than one year. The remittances from new immigrants are not included in the World Bank data (Bilsborrow, Hugo, Oberai, \& Zlotnik, 1997). Second, the data only tallies remittances sent through official channels (e.g., commercial banks and money transfer operators). Given the extensive informal channels (e.g., cash in mail) for remittances in many developing countries, it is very likely to underestimate the total remittance flows (Ratha, 2004).

The model uses agricultural real GDP $(Y)$ as a proxy for economic performance in Kenya and also as a proxy for "poverty". The data is obtained from the Food and Agriculture Organization of United Nations (FAO) database. The agricultural sector in Kenya employs about $75 \%$ of the country's labor force and accounts for $45 \%$ of government revenues. Poverty levels in Kenya, both urban and rural areas, are closely related to agricultural output as a major means of generating income (Gitu, 2004). We, therefore, assume that a fall in agricultural GDP will lead to a harsh economic downturn that translates into rising international remittances, if altruistic motivation dominates.

The host country income, measured by host country GDP per capita, is a significant determinant for remittances due to both increasing quantity demand for immigrant labor force and increasing wages (Straubhaar, 1986). However, as noted by Vargas-Silva and Huang (2006), the host country income can be approximated by the unemployment rate as a better indicator for economic downturn. The variable US denotes the U.S. annual unemployment rate in which a negative relationship is expected between $U S$ and international remittances, no matter the motivation is altruism or self-interest. We obtain the U.S. unemployment data from World Bank (i.e., World Development Indicators (WDI)).

Measured in metric tons, the variable of domestic cement consumption $(H D)$ is a proxy to represent demand on housing construction. Kagochi and Kiambigi (2012) and Osili (2005) investigated Kenya and Nigeria respectively to conclude that migrants' savings in the host country are usually transformed to be assets in the home country in the form of housing and land. When those savings are invested in construction sector output, $H D$ serves as an important indicator in our model to verify remittance motivation. If altruistic motive dominates, migrants will demand relatively less $H D$ during economic downturn in their home country. In contrast, if self-interest motive leads, they will demand more housing as a great investment opportunity to cushion their families. Like Kagochi and Kiambigi (2012), we obtain the same data from Kenya National Bureau of Statistics.

The real exchange rate $(E X)$, the price of home country's currency expressed in terms of the host country's currency, may influence the level of remittances in two directions. If domestic goods and services of home country become less expensive due to currency depreciation (i.e. $E X \downarrow$ ), then the migrants will remit less money to purchase the same consumption bundles as before. In contrast, currency depreciation in the home country may lead its citizens living abroad to feel wealthier. The "wealth effect" will boost their purchasing power back home and encourage more remittances buying more goods, including real estates. At macro level, currency depreciation of home country is assumed to hurt Kenya, which is a net importer. It will result in more economic hardships which translate into more international remittances if the migrant's motive is altruistic. So, the sign of $E X$ in the estimated equation is more likely to be negative (positive), if the altruistic (self-interest) motivation dominates. EX Data is also obtained from the World Bank (WDI).

Inflation (INFL) is measured by the Consumer Price Index (CPI) and defined as declining purchasing power in the home country. In developing countries, the majority in rural area households depends significantly on remittances as the only source of income. Therefore, if migrants' motive of remittances is altruistic, a higher 
inflation which declines household purchasing power is expected to encourage more remittances. CPI data is also obtained from World Bank.

Like the other countries in Sub-Saharan Africa, Kenya's agricultural production depends heavily on natural rainfalls. A drought not only harms farmers in rural areas but also damages income-generating behavior related to agricultural products in urban areas (Gitu, 2004). Davies (2007) indicated that households suffering from drought are expected to receive more remittances from distant areas. We assemble the historical data of drought occurrence in Kenya then define the dummy variable $(D t)$ to explore the relationship between drought and remittances, in which " 1 " is for years that are classified as "drought" and "0" otherwise. We also assume that onset of drought will lead more international remittances if migrants' motive is altruistic.

\section{Methodology and Empirical Results}

\subsection{Methodology}

Following the current financial development literatures, we employ the Autoregressive Distributed Lag (ARDL) model with co-generation approach renovated by Pesaran et al. (2001) to estimate both short-run and long-run elasticities for the determinants of remittances to Kenya. Several advantages of ARDL co-generation model enable us to explore the impacts of determinants in the case of Kenya. First, ARDL yields consistent estimates of long-run coefficients that are asymptotical and irrespective to the order of integration for the explanatory variables. With co-integration techniques which require the underlying series as the bound test, the model does not need to restrict that all the variables have to be integrated at the same order. Second, the ARDL approach provides unbiased estimates of long-run model and valid $t$-statistics even when some independent variables are endogenous as inclusion of dynamics. It may also correct the possible endogenous bias noted by Harris and Sollis (2003). Third, the ARDL model counts error corrections into its lagged periods. As a result, both error correction and autoregressive lag are fully covered for either long-run or short-run relationship among the tested variables. When the error correction is not restricted, the ARDL model automatically becomes an Unrestricted Error Correction (UEC) model. Finally, there are only 41 observations with 7 parameters (i.e., excluding the intercept) in our data set. Compared with the other co-integration techniques requiring large sample size, the ARDL approach works better in estimation for a restively small sample size (Blin \& Quattara, 2009).

Based upon Equation (6), an ARDL representation of the determinants of remittances to Kenya is formulated as

$$
\begin{aligned}
\Delta \operatorname{lnRem}_{t}= & \beta_{0}+\sum \beta_{1 i} \Delta \ln Y_{t-i}+\sum \beta_{2 i} \Delta U S_{t-i}+\sum \beta_{3 i} \Delta \ln H D_{t-i}+\sum \beta_{4 i} \Delta \ln E X_{t-i}+\sum \beta_{5 i} \Delta I N F_{t-i}+\sum \beta_{6 i} \Delta D T_{t-i} \\
& +\beta_{7} \operatorname{lnRem}_{t-1}+\beta_{8} \ln Y_{t-1}+\beta_{9} U S_{t-1}+\beta_{10} \ln H D_{t-1}+\beta_{11} \ln E X_{t-1}+\beta_{12} I N F_{t-1}+\beta_{13} D T_{t-1}+\varepsilon_{t}
\end{aligned}
$$

where $\beta_{0}$ is a drift component and $\varepsilon_{t}$ is white noise error. In equation (7), the terms with summation define the short-run dynamics. All the rest of terms represent the long-run relationship. Similar to the procedure in Pesaran et al. (2001), we start the ARDL process with a bound testing of the presence of a long-run relationship among the variables. The bound testing is determined by $F$-statistic with the null hypothesis of no co-integration in the long-run relationship (i.e. $H o: \beta_{8}=\beta_{9}=\beta_{10}=\beta_{11}=\beta_{12}=0$ ). The decision rule is simple. If $F$-statistic exceeds the upper critical value (i.e. $5 \%$ ), then we reject the null hypothesis of no long-run relationship regardless of the variables order of integration. On the other hand, if the test statistic is less than the lower critical bound, then no co-integration is confirmed in the long-run relationship. We may use information criteria, either Schwartz Bayesian Criteria (SBC) or Akaike Information Criteria (AIC), to construct both long-run and short-run models. However, in case the test statistic falls within the range of two bounds, then it becomes inconclusive.

\subsection{Empirical Results}

As Pesaran et al. (2001) indicated, the ARDL model in co-integration approach does not need to conduct unit root test in advance like the other techniques (e.g., Johansen approach). However, if the order of integration of any pair of variables is higher than one, then the critical bounds defined by Pesaran et al. (2001) will be invalid. As suggested by Blin and Ouattara (2009), before proceeding to the estimation stage, we have to conduct the unit root test to ensure that all variables are either I(0) or I(1) to satisfy the ARDL assumptions.

\subsubsection{Unit Root Test}

We employ the Augmented Dickey-Fuller (ADF) and Phillips-Perron (PP) as the standard tests for unit root in Table 1. The result indicates that all the variables are stationary in Equation (7). In other words, the order of integration for all variables are confirmed at either I(0) or I(1). It is unnecessary to conduct dummy variable $\left(D_{t}\right)$ in unit root test since it is binary at $\mathrm{I}(0)$. With confidence, we may keep on the ARDL methodology to the next stage. 
Table 1. ADF and PP unit root tests (with constant no trend)

\begin{tabular}{llllllr}
\hline Variables & ADF & PP & Variables & ADF & PP & Decision \\
\hline Rem & -0.654 & -0.517 & $\Delta R e m$ & $-7.000^{* * *}$ & $-7.441^{* * *}$ & $\mathrm{I}(1)$ \\
$Y$ & -0.896 & -0.938 & $\Delta Y$ & $-7.787^{* * *}$ & $-9.066^{* * *}$ & $\mathrm{I}(1)$ \\
$U S$ & -1.849 & -2.174 & $\Delta U S$ & $-4.645^{* * *}$ & $-4.547 * * *$ & $\mathrm{I}(1)$ \\
$H D$ & 0.266 & -0.087 & $\Delta H D$ & $-5.705^{* * *}$ & $-5.733^{* * *}$ & $\mathrm{I}(1)$ \\
$E X$ & -0.562 & -0.608 & $\Delta E X$ & $-4.764 * * *$ & $-4.760^{* * *}$ & $\mathrm{I}(1)$ \\
$I N F$ & $-3.682^{* * *}$ & $-3.633^{* * *}$ & $\Delta I N F$ & $-7.002^{* * *}$ & $-7.340^{* * *}$ & $\mathrm{I}(0)$ \\
\hline
\end{tabular}

$* * *$ significance at $1 \%$ level. The critical values are based on the finite sample calculation in McKinnon (1991).

\subsubsection{Long-Run Relationship}

Before running the regression for Equation (6), we need one more step, a bound test, to confirm that a long-run relationship exists among variables. Table 2 shows the $F$-statistic is above 5\% critical value defined in Pesaran et al. (2001). We can reject the null hypothesis of no co-integration and confirm a long-run relationship among variables in the period of 1970 to 2010 for remittances to Kenya.

Table 2. Bounds tests for the existence of co-integration

\begin{tabular}{cll}
\hline F-Statistic & $5 \%$ Critical Value & \\
\hline & $\mathrm{I}(0)$ & $\mathrm{I}(1)$ \\
199.95 & 2.22 & 3.39 \\
\hline
\end{tabular}

After the long-run relationship is confirmed, the estimates of coefficients in Equation (6) are shown in Table 3 based on the Schwartz Bayesian Criteria (SBC). The long-run ARDL regression has an $R^{2}$ of 0.96 as a good fit. The selected ARDL with the order $(1,1,1,1,1,0$, and 0$)$ over variables also shows the significance in standard diagnostic tests, including normality, heteroscedasticity, functional form and serial correlation. The long-run ARDL regression has an adjusted $R^{2}$ of 0.96 as a good fit. A $5 \%$ significance of US unemployment rate indicates a negative relationship between $U S$ and international remittances, no matter the motivation is altruism or self-interest. It confirms that economic downturn in the host country lowers remittances to Kenya as predicted in Section 3. In the long run, $1 \%$ increase in US unemployment, ceteris paribus, will result in $0.09 \%$ drop in international remittances.

Table 3. Estimates of long-run coefficients

\begin{tabular}{lcc}
\hline Variable & Coefficient & t-ratio \\
\hline Intercept & -1.69 & $2.31^{* *}$ \\
Remittance (Rem- 1$)$ & 0.56 & $4.16^{* * *}$ \\
Agriculture GDP $(Y)$ & -0.65 & -0.78 \\
US Unemployment $(U S)$ & -0.09 & $-2.41^{* *}$ \\
Housing Demand $(H D)$ & 0.61 & $2.99^{* * *}$ \\
Exchange Rate $(E X)$ & 0.55 & $2.23^{* *}$ \\
Consumer price inflation (INFL) & -0.002 & -0.41 \\
Drought $(D t)$ & -0.01 & -0.08
\end{tabular}

Results based on Akaike's Information Criteria (AIC) and Schwartz Bayesian Criteria (SBC) suggest that the process is an AR(1). $* *$ significance at $5 \%$ level; ***significance at $1 \%$ level. Adj. $\mathrm{R}^{2}=0.96$; Wald $F$-Statistic $=169.76[0.00] * * *$; DW Statistics $=1.96$.

Surprisingly, the signs of coefficients for all independent variables which verify remittance motivation show the opposite direction to against altruism, including agriculture GDP $(Y)$, housing demand $(H D)$, exchange rate $(E X)$, inflation $(I N F L)$ and drought $(D t)$. Among them, housing demand and exchange rate are statistically significant 
at $1 \%$ level and $5 \%$ level respectively to support the self-interest motivation of remittances. The coefficient of $H D$ indicates that $1 \%$ increase in housing construction demand, ceteris paribus, will result in $0.61 \%$ increase in international remittances to Kenya in the long-run. With self-interest motivation, migrants who are working oversea will demand more housing in Kenya as a great investment opportunity. The result also confirms the finding in Kagochi and Kiambigi (2012) and Osili (2005) in which migrants' savings in the host country are transformed to be local assets (e.g. housing and land) in the home country. Given the positive sign of exchange rate, a depreciation $(E X \downarrow)$ of the Kenya shilling against the US dollar leads a decrease in remittances which also violates the altruistic assumption. The result shows that migrants do not remit more back home when Kenya experiences economic harsh times due to currency depreciation as a net importer. Instead, $1 \%$ increase in exchange rate (appreciation) will result in $0.55 \%$ increase in international remittances to Kenya in the long-run. It is more likely to support self-interest motivation because migrants tend to remit a greater amount back home given more investment opportunities in a better home economy. Furthermore, the other three "altruistic" variables including agriculture GDP $(Y)$, inflation (INFL) and drought $(D t)$, do not show statistical significance. The signs of coefficients are negative in opposition to the altruism motivation in Kenyan case.

\subsubsection{Short-Run Dynamics}

As all variables are co-integrated, it is suitable to apply the error correction mechanism (ECM) to examine the short-run dynamics for remittances to Kenya. Table 4 exhibits the ECM results associated with the SBC criteria. The negative sign of ECM coefficient shows significance at $1 \%$ level. A highly significant $E C M$ not only confirms the existence of a stable long-run relationship but also indicates a fast adjustment speed to restore equilibrium in a dynamic model (Bannerjee, Dolado, \& Mestre, 1998); that is, a -0.90 coefficient of ECM (1) implies that deviation from the long-term growth rate of remittances can be corrected by $90 \%$ in the next period.

All the statistics in Table 4 support the long-run findings in the short run dynamics. They indicate that none of altruistic motive variables, including agricultural GDP, inflation and drought, are significantly related to remittances in the short-run. Again, the housing demand, serving as a variable strongly revealing self-interest motivation, determines the remittances at a $10 \%$ significance level in the short-run. A positive short-run relationship between self-interest motivation and remittances are reconfirmed in the case of Kenya.

Table 4. Results of error correction model

\begin{tabular}{lcc}
\hline Variable & Coefficient & t-ratio \\
\hline Intercept & 0.01 & 0.13 \\
$\Delta$ Rem (1) & 0.69 & $2.67^{* *}$ \\
$\Delta Y$ & -0.77 & -0.94 \\
$\Delta U S$ & -0.09 & $-1.90^{*}$ \\
$\Delta H D$ & 0.50 & $1.71^{*}$ \\
$\Delta E X$ & 0.40 & 0.77 \\
$\Delta I N F L$ & -0.001 & -0.04 \\
$\Delta D t$ & -0.02 & 0.29 \\
$E C M(1)$ & -0.90 & $-3.50^{* * *}$
\end{tabular}

$\operatorname{ARDL}(1,1,1,1,1,0$, and 0$)$ is based on Schwartz Bayesian Criteria (SBC).*significance at $10 \%$ level; **significance at $5 \%$ level; $* * *$ significance at $1 \%$ level. Adj. $\mathrm{R}^{2}=0.38 ;$ Wald $F$-Statistic $=2.63[0.02] * * *$ DW Statistic $=2.01$.

\section{Concluding Remarks}

The paper investigates whether international remittances to Kenya are motivated by altruism or self-interest by using an ARDL model. Contrary to the other studies in this field conducted for the SSA, our empirical findings suggest that self-interest rather than altruism plays a more important role in determining the amount of remittances to Kenya. The economic status of migrants' host country is also strongly related to the amount of remittances. Housing construction demand and exchange rates are the two strong drivers of international remittances to Kenya. The altruism measurements including agricultural GDP, inflation and drought do not seem to explain international remittances to Kenya. 
The dominance of self-interest motivation for remittances to Kenya may be explained by its socioeconomic composition of international immigrants. Like most SSA countries, migration from Kenya to Western world, especially to the U.S., is relatively expensive given the local low income level. Only the relatively wealthy households are able to send migrants oversea then benefit from international remittances. As noted by Murrugarra, Larrison, \& Sasin (2010), migration has both economic and social costs which require capable migrants to use resources that the poorest may not have access to. Those resources include financial assets (e.g. income, savings, credit), human capital (e.g., education, training, entrepreneurship), social networks and political strength. To the migrants from wealthier households in Kenya, altruism motivation is weaker because their families may not be affected by food shortage related to economic hardships. Among SSA countries, as summarized in Hoddinott (1994), wealthier parents in Kenya and Botswana received a larger share of migrant earnings through remittances. Studies elsewhere also indicate that only people coming from higher income families are able to migrate to the US. For example, in Nicaragua, migrants to the U.S. from higher income families are significantly more than those to Costa Roca. Our findings also debunk one of popular media's assertions that Kenyans in the Diaspora remit more during the hard time, especially in drought time, to cushion their relatives back home against inflated financial burden. Indeed, the rising remittances might be a reflection of Kenyans in the Diaspora taking advantage of the depressed market conditions such as lower priced property market, equity market and other investments. Kenyan migrants are also able to take advantage of favorable exchange rate during hard times which is occasioned by the need for the country to accumulate more foreign exchange reserves to pay for importation of basic commodities such as food.

Given the dominance of self-interest motivation for remittances, we recommend the Kenyan government to facilitate channeling of remittances into manufacturing and financial sectors to boost its economic growth. One way of doing so is to promote savings (e.g. a higher saving interest rate) from remittances into financial institutes where the money can be loans to small business for job creation. In addition, government should enact policies which encourage migrants to engage in transferring human capital and technology back to Kenya. Otherwise, the poor cannot benefit from increasing remittances in the long run. The government is also supposed to engage in bilateral immigration agreements with developed countries. A lower immigration cost will avail more people from poor families to participate in immigration with resultant increase in altruistic related remittances and poverty reduction.

\section{References}

Banerjee, A., Dolado, J. J., \& Mestre, R. (1998). Error-correction mechanism tests for cointegration in a single-equation framework. Journal of Time Series Analysis, 19, 267-83. http://dx.doi.org/10.1111/1467-9892.00091

Becker, G. S. (1974). A theory of social interactions. Journal of Political Economy, 82, 1063-1093. http://dx.doi.org/10.1086/260265

Bendixen, S. (2010). Remittances to Kenya. In FAR Conference, Nairobi, Kenya on October 19th.

Bilsborrow, R. E., Hugo, G., Oberai, A. S., \& Zlotnik, H. (1997). International migration statistics: Guidelines for improving data collection systems. Geneva: International Labor Office.

Blin, M., \& Ouattara, B. (2009). Foreign direct investment and economic growth in Mauritius: Evidence from bounds test cointegration. Economie Internationale CEPII Research Center, 10, 47-61.

Bouhga-Hagbe, J. (2006). Altruism and workers' remittances: Evidence from selected countries in the Middle East and Central Asia. IMF Working Papers, 6, 130.

Brown, R. P. C. (1997). Estimating remittance functions for pacific island migrants. World Development, 25, 613626. http://dx.doi.org/10.1016/S0305-750X(96)00122-2

Catrinescua, N., Leon-Ledesmab, M., Pirachac, M., \& Quillind, B. (2009). Remittances, institutions, and economic growth. World Development, 37, 81-92. http://dx.doi.org/10.1016/j.worlddev.2008.02.004

Davies, S. (2007). Remittances as insurance for idiosyncratic and covariate shocks in Malawi: The importance of distance and relationship. MPRA Paper 4463, University Library of Munich, Germany.

Funkhouser, E. (1995). Remittances from international migration: A comparison of El Salvador and Nicaragua. The Review of Economics and Statistics, 77, 137-46. http://dx.doi.org/10.2307/2109999

Gitu, K. W. (2004). Agricultural development and food security in Kenya: Building a case for more support. Technical Report Presented to FAO, September 2004.

Guarnizo, L. E. (2003). The economics of transnational living. International Migration Review, 37, 666-699. 
http://dx.doi.org/10.1111/j.1747-7379.2003.tb00154.x

Harris, R., \& Sollis, R. (2003). Applied time series modelling and forecasting. West Sussex: Wiley.

Hoddinott, J. (1994). A model of migration and remittances applied to Western Kenya. Oxford Economic Papers, $46,459-476$.

Kagochi, J. M., \& Kiambigi, M. (2012). Remittances' influence on housing construction demand in sub-Saharan Africa: The case of Kenya. African Development Review, 24, 255-265. http://dx.doi.org/10.1111/j.1467-8268.2012.00321.x

Leon-Ledesma, M., \& Piracha, M. (2004). International migration and the role of remittances in Eastern Europe. International Migration, 42, 65-84. http://dx.doi.org/10.1111/j.0020-7985.2004.00295.x

Lucas, R. E. B., \& Stark, O. (1985). Motivations to remit: Evidence from Bostwana. The Journal of Political Economy, 93, 901-918. http://dx.doi.org/10.1086/261341

Murrugarra, E., Larrison, J., \& Sasin, M. (2010). Migration and poverty: Towards better opportunities for the poor. World Bank Publications.

Osili, U. (2005). Migrants and housing investments: Theory and evidence from Nigeria. Economic Development and Cultural Change, 52, 821-849. http://dx.doi.org/10.1086/420903

Pesaran, M. H., Shin, Y., \& Smith, R. J. (2001). Bounds testing approaches to the analysis of level relationships. Journal of Applied Econometrics, 16, 289-326. http://dx.doi.org/10.1002/jae.616

Poirine, B. (1997). A theory of remittances as an implicit family loan arrangement. World Development, 25, 589611. http://dx.doi.org/10.1016/S0305-750X(97)00121-6

Ratha, D. (2004). Understanding the importance of remittances. World Bank, Washington, DC.

Roberts, B., \& Banaian, K. (2004). Remittances in Armenia: Size, impacts, and measures to enhance their contribution to development. Special Study for USAID/Armenia.

Straubhaar, T. (1986). The determinants of workers' remittances: The case of Turkey. Emerging Markets Finance and Trade, 41(3), 53-69.

Tchouassi, G. (2010). Altruistic preferences as motivation for migrants in the diaspora to remit to home communities. Research in Applied Economics, 2, 1-18.

Thanh, L. (2009). Trade, remittances, institutions, and economic growth. The International Economic Journal, 23, 391-408. http://dx.doi.org/10.1080/10168730903119443

Vargas-Silva, C., \& Huang, P. (2006). Macroeconomic determinants of workers' remittances: Host versus home country's economic conditions. Journal of International Trade and Economic Development, 15, 81-99. http://dx.doi.org/10.1080/09638190500525779

Woodruff, C., \& Zenteno, R. (2004). Remittances and microenterprises in Mexico. Working Paper. Department of Economics, University of California, San Diego.

World Bank. (2011). Migration and remittances factbook. Migration and Remittances Unit, The World Bank, Washington, DC.

\section{Copyrights}

Copyright for this article is retained by the author(s), with first publication rights granted to the journal.

This is an open-access article distributed under the terms and conditions of the Creative Commons Attribution license (http://creativecommons.org/licenses/by/3.0/). 